Article

www.mdpi.com/journal/remotesensing

\title{
Using MODIS-NDVI for the Modeling of Post-Wildfire Vegetation Response as a Function of Environmental Conditions and Pre-Fire Restoration Treatments
}

\author{
Jose Raul Romo Leon ${ }^{1, *}$, Willem J.D. van Leeuwen ${ }^{1,2}$ and Grant M. Casady ${ }^{3}$ \\ 1 School of Natural Resources and the Environment \& Arizona Remote Sensing Center, 1955 E. Sixth \\ Street, The University of Arizona, Tucson, AZ 85721, USA; E-Mail: leeuw@email.arizona.edu \\ 3 Department of Biology, Robinson Science Hall 205, Whitworth University, 300 West Hawthorne \\ Rd., Spokane, WA 99251, USA; E-Mail: gcasady@whitworth.edu \\ * Author to whom correspondence should be addressed; E-Mail: joser2@email.arizona.edu; \\ Tel.: +1-520-626-0058; Fax: +1-520-621-3816.
}

Received: 31 January 2012; in revised form: 29 February 2012 / Accepted: 29 February 2012 / Published: 2 March 2012

\begin{abstract}
Post-fire vegetation response is influenced by the interaction of natural and anthropogenic factors such as topography, climate, vegetation type and restoration practices. Previous research has analyzed the relationship of some of these factors to vegetation response, but few have taken into account the effects of pre-fire restoration practices. We selected three wildfires that occurred in Bandelier National Monument (New Mexico, USA) between 1999 and 2007 and three adjacent unburned control areas. We used interannual trends in the Normalized Difference Vegetation Index (NDVI) time series data derived from the Moderate Resolution Imaging Spectroradiometer (MODIS) to assess vegetation response, which we define as the average potential photosynthetic activity through the summer monsoon. Topography, fire severity and restoration treatment were obtained and used to explain post-fire vegetation response. We applied parametric (Multiple Linear Regressions-MLR) and non-parametric tests (Classification and Regression Trees-CART) to analyze effects of fire severity, terrain and pre-fire restoration treatments (variable used in CART) on post-fire vegetation response. MLR results showed strong relationships between vegetation response and environmental factors $(p<0.1)$, however the explanatory factors changed among treatments. CART results showed that beside fire severity and topography, pre-fire treatments strongly impact post-fire vegetation response.
\end{abstract}


Results for these three fires show that pre-fire restoration conditions along with local environmental factors constitute key processes that modify post-fire vegetation response.

Keywords: wildfire; remote sensing; restoration; disturbance; experiment; statistical models

\section{Introduction}

Natural disturbances like wildfire events can rapidly modify the landscape, often causing substantial economical losses and a drastic shift in ecological processes [1]. Restoration techniques have been implemented on many forested areas of the south west US to increase vegetation stand resistance to the effects of large wildfires [2-4]. It is important to evaluate the impact of restoration management practices while taking into account other influential environmental factors that could contribute to the post-fire vegetation response, in order to make informed management decisions.

Ecological disturbances are often discrete events in time affecting ecosystem communities and populations by shaping their structures, redistributing their resources, and modifying the biophysical environment at different scales [5-7]. The most important characteristic of disturbance events consists in the variation of their attributes such as their spatial distribution, frequency, spatial extent and magnitude [8]. Disturbance characteristics change through space and time [5] due to climatic, ecologic or anthropogenic factors. In western North America, wildfire is considered to be one of the most important natural ecological disturbance, due to its influence and impact on vegetation communities [9]. Fire severity is dictated by complex interactions of weather and terrain conditions that affect combustion processes [10,11]. Also, soil composition and vegetation arrangement and amount dictates the size and impacts of fire $[12,13]$. In this study we refer to burn or fire severity as the change that we can observe between before and after fire on vegetation cover. The approaches used for its measurement and assessment have been documented [14-16].

Wildfires are extremely complex phenomena in terms of the number of environmental conditions that regulates their magnitude and ecological impact [17]. These conditions vary in space and time as in the case of climate and topography, and by management of natural resources as in the case of restoration treatments to mitigate fire hazard. Previous work suggests high correlation between climatic conditions and wildfire size and severity, depending on land cover, fuel distribution and composition, and location of the area [18]. However, association between area burned per year and climate often presents nonlinear relationships and large fires could be the consequence of small changes in mean climatic conditions, because wild fires are better explained by individual extreme events [9]. According to predicted scenarios for the southwest USA, temperatures will rise, and precipitation will diminish during the present century [19]. This fluctuation in climatic conditions, to warmer and dryer stages will likely result in larger, more frequent, and more severe fires for the western US forests $[1,20]$.

Fire suppression practices in some U.S. forests have resulted in the accumulation of fuel, and the modification of the fire regime, potentially causing fewer but larger and more severe fires [21,22]. On the other hand, restoration techniques focus on the mitigation of fire effects and the reestablishment of ecological process such as the natural fire regime [23]. Some of the most common restoration 
techniques to mitigate fires focus on forest fuel reduction, either by thinning trees present in a delimited area, or conducting prescribed and controlled burning of strategic forest areas or removal of fuels by mechanical means [24,25]. The presence of pre-fire anthropogenic treatments has been shown to reduce fire severity [4,26,27], and according to these findings vegetation response would be different for areas that were treated and burned and areas that did not receive any treatment and were also burned by the same fire. In this research we further assess the effect of pre-fire treatments by using remote sensing tools, which present the opportunity for managers and scientist for the evaluation and continuous monitoring of vegetation response post-fire.

Our objectives in this research were: (1) to evaluate the influence of a selected set of environmental factors to describe post-fire vegetation response, and (2) examine if pre-fire restoration treatments have a significant effect in post-fire vegetation recovery. Figure 1 explains the expected behavior of a forest system with a given set of environmental conditions. We expect fire severity, environmental factors and pre-fire vegetation treatments to be major drivers of vegetation response after fire.

The goal of this research was to evaluate post-fire vegetation response for three fires in north central New Mexico, as a function of local environmental factors and pre-fire restoration practices that took place in part of the burned areas. Surprisingly, research has been limited, and little literature can be found regarding the assessment of the collective effect of the factors previously mentioned on post-wildfire vegetation response [28].

Figure 1. Conceptual representation of vegetation response (production proxy) to climate, restoration and wildfire disturbance. During wildfire events restored-burned areas are expected to have less damage due to a reduction in fire severity.

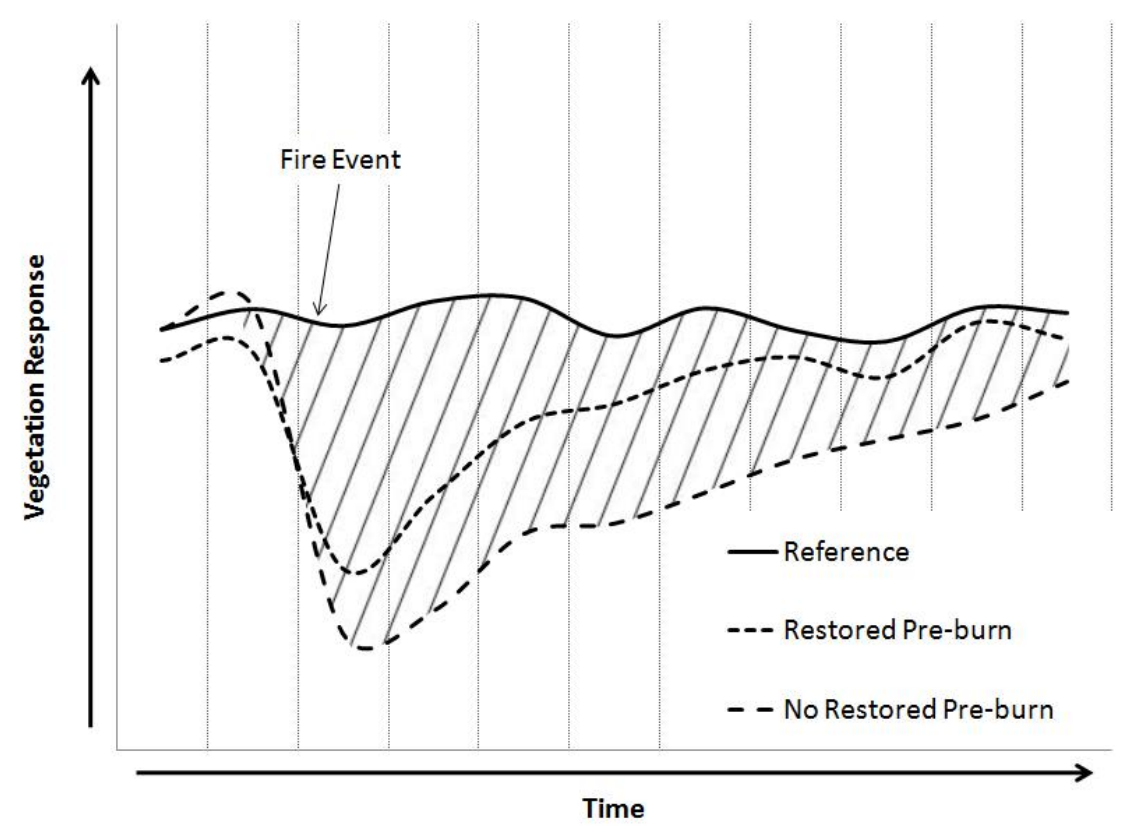

\subsection{Monitoring and Modeling Wildfire Effects}

The use of remote sensing technologies constitutes a good source of information and data to assess vegetation response and trends [29-33]. Remote sensing tools provide the means to assess biophysical variables such as location, spectral signature of objects, chlorophyll absorption characteristics, 
moisture content of vegetation and soil, elevation and topography [34]. These variables are tightly related to key vegetation biological activities such as vegetation photosynthetic activity rate $[35,36]$, and to physical aspects of the terrain such as elevation, aspect and slope. Current satellites provide constant monitoring opportunity across extensive landscapes. These datasets are generally available for multiple temporal and spatial resolutions [37,38].

Remote sensing techniques have been extensively used to monitor and assess diverse aspects of wildfire events [14,39], ranging from spatial studies to temporal assessment of processes[30,32,40,41]. Previous research has taken advantage of the temporal, spectral, and spatial characteristics of Landsat and MODIS to study post- and pre- wildfire vegetation responses [40,42].

\subsection{Modeling Post-Fire Trend}

In this research we use two different widely used modeling approaches to achieve our goal. Stepwise Multiple Linear Regression (MLR) is a parametric statistical technique. The procedure starts with the tentative explanatory model using a set of response and explanatory variables, and analyzes secondary models that are derived from the same explanatory variables. The final model is constructed with the independent variables that significantly contribute to the explanation of the response [43]. Using these parametric and non-parametric statistical techniques we evaluate post-fire vegetation response as a function of a set of local environmental variables including topography, fire severity and pre-fire restoration treatments.

Classification and Regression Tree (CART) has been used in many disciplines [44], including ecological analysis with data from multiple sources that are very complex to manage, and often have problems such as missing values, nonlinearity and unbalance [45,46]. The decision tree framework [46] can help discern the importance and impact of explanatory variables on the response variables employing non-parametric techniques that allow the use of categorical and continuous data. CART models offer an easy to follow graphical representation of the tree partition, telling us which variable relates to the response in hierarchical order.

\section{Data and Methods}

\subsection{Analyzing Fire Events in the South West USA}

This research is based on the premise that post-fire vegetation responses are influenced by environmental factors which might vary in importance, depending on geographic location. Also we pose that pre-fire restoration techniques applied to locations within a fire will likely affect post-fire vegetation response resulting in fire damage. Therefore vegetation stand conditions and response due to these conditions will differ among treatments. The following sections provide a description of the study area and the datasets used to derive our set of response and explanatory variables, including the method utilized to test environmental drivers of post-fire. The methodological pathway used in this study is sketched in Figure 2. 
Figure 2. Parametric and non-parametric approaches were used to evaluate post-fire response drivers. Remotely sensed and ancillary datasets were used to derive response and explanatory variables.

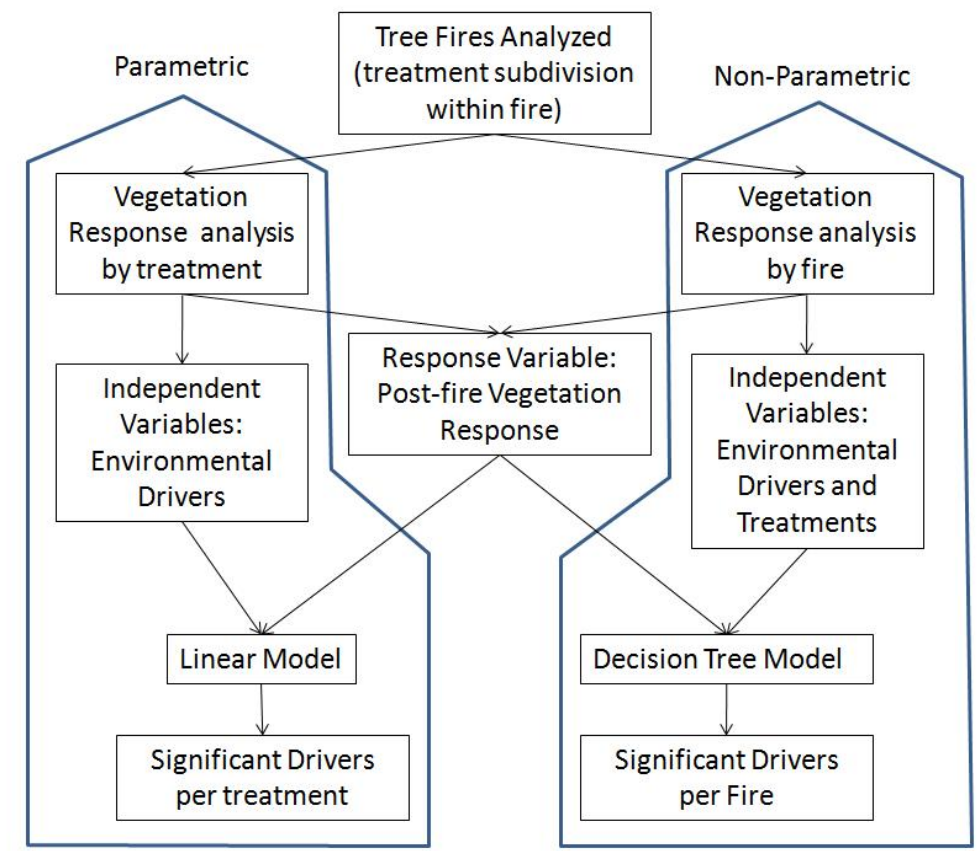

\subsection{Study Area}

This study takes place in Bandelier National Monument which is located in north central New Mexico (35 53'38'N $\left.106^{\circ} 17^{\prime} 02^{\prime \prime} \mathrm{W}\right)$ in the area known as the Pajarito Plateau. The approximate extent of the monument is 13,290 ha, and its elevation above sea level ranges from around 1,680 meters near the Rio Grande River to approximately 3,240 $\mathrm{m}$ at the summit of the formation known as Cerro Grande. Bandelier National Monument was created in 1916 to preserve the cultural heritage and history from pre-Hispanic settlements and communities in the area (Figure 3).

The landscape in Bandelier is composed of sloped mesas cut by steep-walled canyons. The average annual precipitation ranges from 330 to $460 \mathrm{~mm}$ [47,48] and about $45 \%$ of it occurs during July, August, and September. The average daytime temperatures range from $32.2{ }^{\circ} \mathrm{C}$ in the summer $\left(\max .=41.1^{\circ} \mathrm{C}\right)$ to $-9.4{ }^{\circ} \mathrm{C}$ in the winter $\left(\min .=-30.6{ }^{\circ} \mathrm{C}\right)$. Conley et al. [49] described 3 major types of vegetation in the park. Lower elevations $(1,680-2,015 \mathrm{~m})$ are characterized as pinion-juniper woodland. Mid-elevation transitional areas $(2,015-2,440 \mathrm{~m})$ are characterized by an overstory of ponderosa pine (Pinus ponderosa) and understory of Gambel oak (Quercus gambelii), New Mexican locust (Robinia neomexicana), and mountain mahogany (Cercocarpus mountanus.). Upper elevations $(2,440-3,240 \mathrm{~m})$ are classified as mixed-conifer where Douglas fir (Pseudotsuga menziesii), white fir (Abies concolor), and spruce (Picea spp.) are found [50].

Forest fuels have been increasing in the last decades [51], as a consequence of anthropogenic and natural conditions converging in this area [22]. Furthermore, periodic decreases in winter precipitation cause the forest vegetation to desiccate earlier and remain desiccated longer during the fire season [51], increasing the potential for intense fires in the zone. In an attempt to mitigate the intensity of fire 
events in the area, several restoration techniques have been implemented around the monument, however their efficiency in mitigating the effects of wildfire have not been evaluated thoroughly.

Figure 3. (a) Study area location in New Mexico, including burned areas and the reference areas, here the Frijoles Canyon fire scar in green, the Mid Elevation Mesa fire scar in cyan and the Capulin fire scar in red, all with their respective adjacent non treated and non burned areas (see legend). (b) Pre-fire treated areas (in orange) within the Frijoles fire perimeter (in green). (c) Pre-fire non-treated area (yellow) at La Mesa fire perimeter (in cyan).

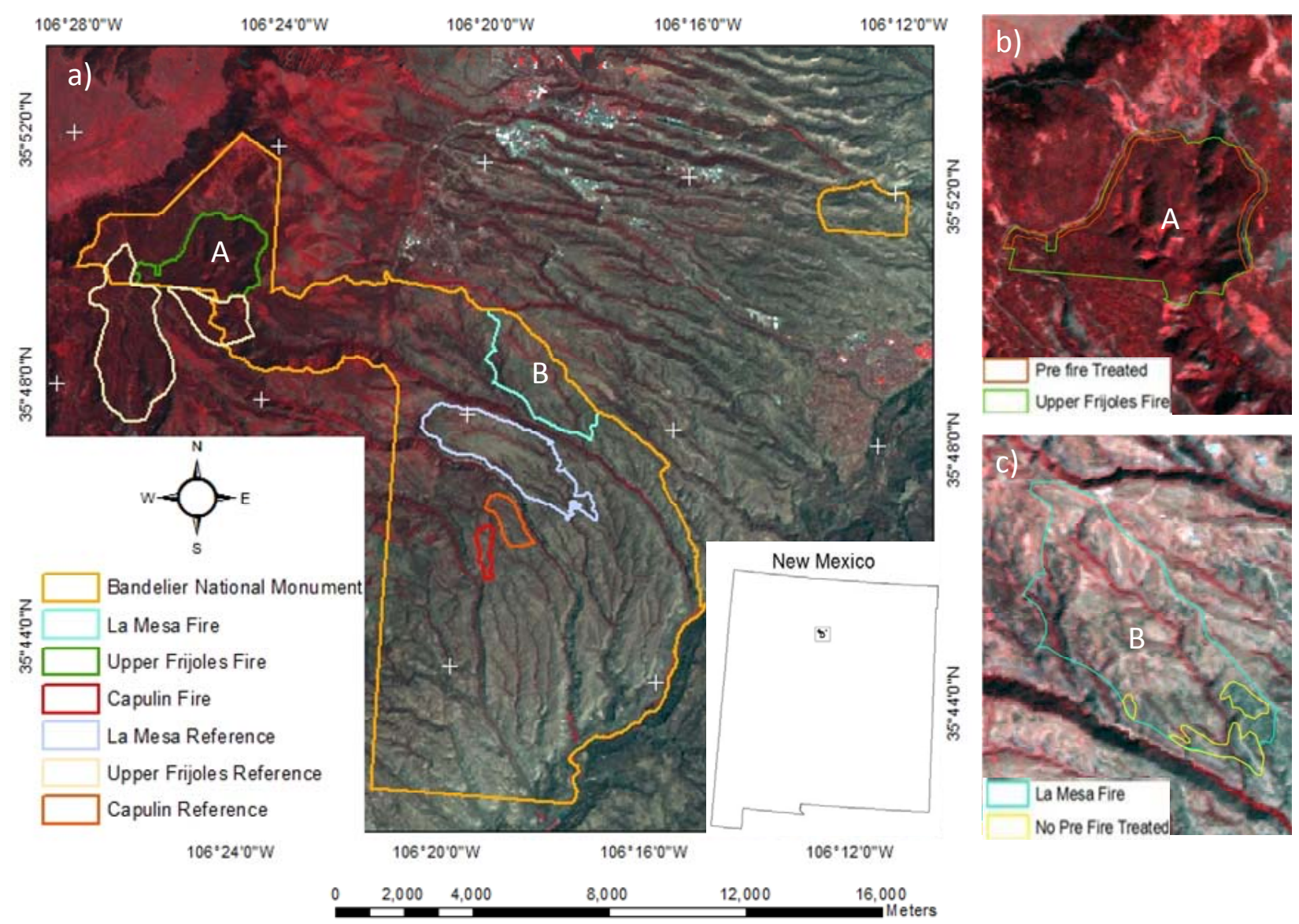

\subsection{Research Design}

Within the area of Bandelier National Monument, we utilized three recent fires to conduct our studies (Figure 3). These fires were: (1) Capulin fire, which occurred during 2006 from 21 May to 24 June, the area burned was around $51 \mathrm{Ha}$, (2) Mid Elevation Mesas fire, which occurred during 1999 from 4 March to 10 March, the area burned was around 568 ha and (3) Upper Frijoles fire, which occurred during 2007 from 5 November to 31 December, the area burned was around 567.5 ha.

For each fire, treatment types were identified according to restoration or mitigation actions that took place before the fire happened. For the three fires we surveyed at Bandelier National Monument, we identified burned areas that received no pre-fire treatment, and adjacent reference areas (not burned by the fire) that according to experts, sustain similar vegetation conditions to the ones present in each of 
the burned areas before the fire. Two of the fires we used for this study (Mid Elevation Mesas and Upper Frijoles Fire) had pre-fire treated areas.

\subsection{Vegetation Response after Fire}

The Normalized Difference Vegetation Index (NDVI) measures the amount of potential photosynthetic activity of vegetation [52], by using the strong relationship of the index to the fraction of photosynthetic active radiation (fAPAR) [53,54]. NDVI is calculated as follows:

$$
\mathrm{NDVI}=(\rho \mathrm{NIR}-\rho \operatorname{Red}) /(\rho \mathrm{NIR}+\rho \mathrm{Red})
$$

Even though we cannot consider NDVI as a direct measurement of productivity, it is tightly linked to photosynthetic active radiation (FPAR), which is a factor that regulates production [55-58]. Therefore, it can be used as an accurate proxy for vegetation dynamics after each fire. We generate a series of statistics based on the response to analyze similitude and differences among fires and fire treatments.

In this research we use the average of the NDVI for the monsoon season, derived from the MODIS sensor at $250 \mathrm{~m}$ spatial resolution. This average is generated by calculating the mean of MODIS-NDVI 16 day composite product (MOD13Q1) for the periods 13 to 17, which corresponds to the composites during July, August and September. For the treatments in each fire, we generated the monsoon averages for each year after the fire occurred. After obtaining the monsoon averages post-fire, we established a least square relationship using the following model to obtain the trend in vegetation response after each fire:

$$
\operatorname{NDVI}(\text { monsoon })=\beta_{0}+\beta_{1} \text { year }
$$

where NDVI (monsoon) is the monsoon average value for NDVI, and year is the number of years since burn, particular for each fire. Finally, we used the slope $\left(\beta_{1}\right)$ in our study as our indicative of post-fire vegetation trend for further analysis. Figure 4 shows the potential response from vegetation according to pre-fire treatment.

\subsection{Environmental and Human Factors Affecting Vegetation Response}

To find the local environmental variables that influence vegetation recovery, we derived a set of explanatory environmental variables from Landsat TM5 and other ancillary data sources. Specifically fire severity information and terrain characteristics (elevation, aspect and slope) were calculated, along with the location of pre-fire restoration treatments and specific management approaches that took place within the fire, previous to the event.

We prepared a collection of Landsat TM reflectance data (30 $\mathrm{m}$ spatial resolution). Two images per fire were selected, one during a growing season previous to the fire event, and one during the growing season after the fire event (Table 1). These images where preprocessed to reduce atmospheric effects [59] and standardize the quality of the dataset among fires. 
Figure 4. (A) Example of how the response variable was derived, for each of the MODIS pixels in one of our study sites (Mid Elevation Mesa fire, 1999). Vegetation trend was calculated by extracting the slope of a linear model, fitted with the NDVI integrations of the monsoons after the fire. (B) Example of how vegetation responses differ from treatments within fires. (C) The linear trends derived from the data in (B). Average NDVI is calculated for growing season periods 13 to 17 .

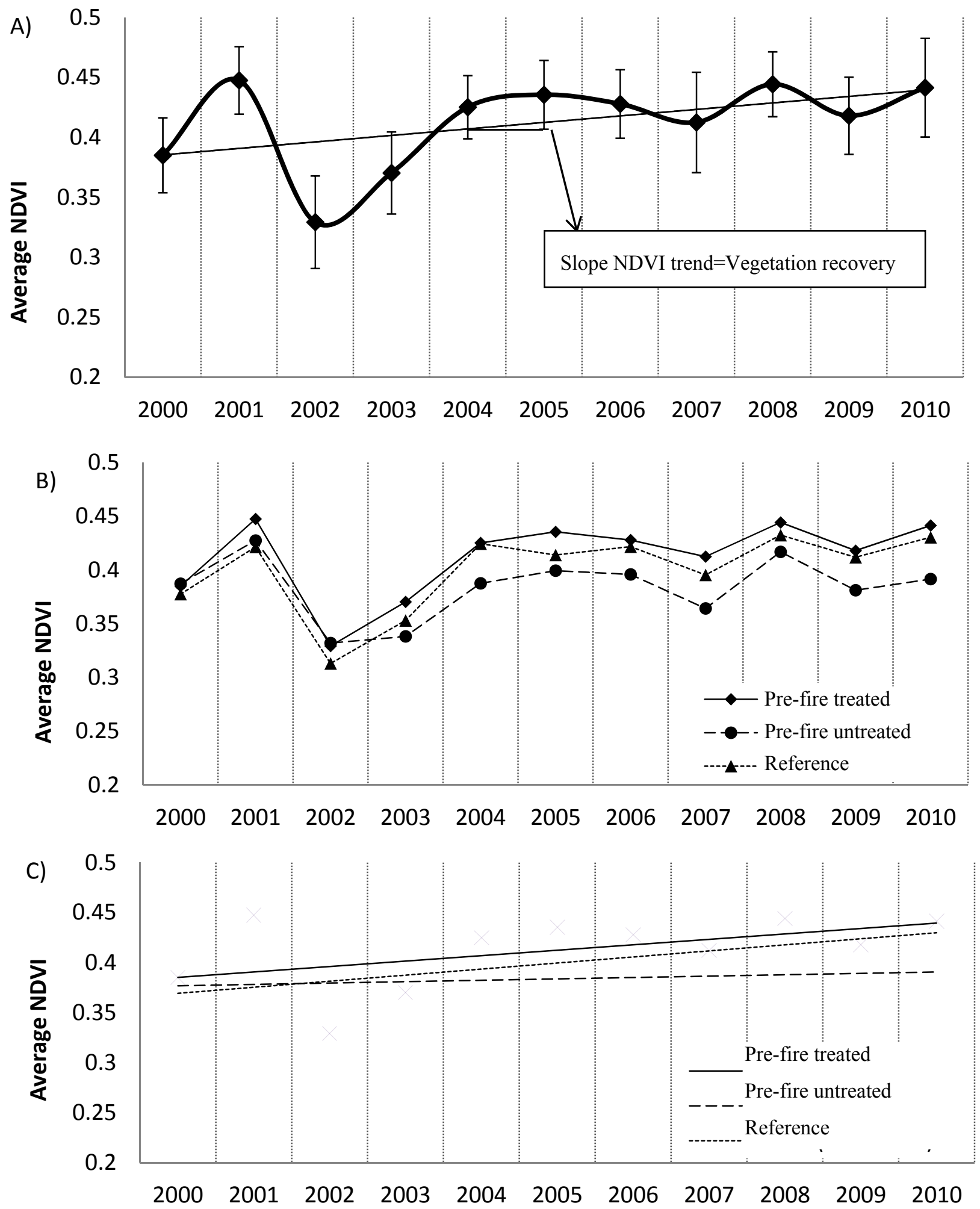


Table 1. Fire event and Landsat TM5 scene dates.

\begin{tabular}{cccc}
\hline Fire Name & Time of Fire & Scene Before Fire & Scene After Fire \\
\hline Capulin & $5 / 21 / 06-6 / 24 / 06$ & $9 / 24 / 2004$ & $8 / 16 / 2007$ \\
Mid Elevation Mesas & $3 / 4 / 99-3 / 10 / 99$ & $8 / 23 / 1998$ & $9 / 13 / 2000$ \\
Upper Frijoles & $11 / 5 / 07-12 / 31 / 07$ & $8 / 16 / 2007$ & $8 / 2 / 2008$ \\
\hline
\end{tabular}

From each of the two images derived per fire we generated the Normalized Burn Ratio (NBR) as an indicator of fire severity $[16,42]$. NBR is derived as:

$$
\mathrm{NBR}=(\rho \mathrm{NIR}-\rho \mathrm{SWIR}) /(\rho \mathrm{NIR}+\rho \mathrm{SWIR})
$$

The NBR has performed well when comparing burn severity in situ to the index measurements [15], and it is used in a similar way to the NDVI but instead of a red band used to assess chlorophyll content of leaves and tissues, the NBR uses short wave infra red to assess water content of soil and leaves [16]. The Difference Normalized Burn Ration (DNBR) was computed to obtain a measurement of the magnitude of change due to the wildfire event $[16,60]$ (Figure 5). DNBR is generated as:

$$
\mathrm{DNBR}=\text { Pre-Fire NBR }- \text { Post-Fire NBR }
$$

A Digital Elevation Model (DEM) for the study areas was provided by the National Elevation Dataset (NED) through the USGS, at 30 meter resolution. The DEM was surveyed and filled to correct for errors [61] and sinks. From the corrected DEM we derived elevation, aspect and slope of the terrain to further inform our model regarding the physical characteristics of the zone [62,63]. Elevation generally affects climatic conditions, it is generally accepted that temperature decrease and precipitation increases at higher elevations, therefore it is an excellent predictor of climatic variation at local scales due to the usually large sampling scale provided by the DEM's [64,65]. Slope and orientation of the mountains are known to affect precipitation, radiation exposition and thermodynamic processes related to wind [65-67]. In general abrupt topographic changes can bring sharp changes in temperature and precipitation; therefore these variables can be used as a proxy to analyze local climatic variability to explain differences in vegetation trends from one location to another.

In this study we consider elevation and topography as a proxy for climatic variation within the study area, as well as an indicator of spatial arrangement and morphology of the land surface (Figure 5). According to previous findings, topography is also significantly related to availability and distribution of resources at different scales over the landscape [68], like water availability and its flow and distribution in the soil [67,69-72], soil erosion [73,74], energy exchange and wind exposure [66,75], and land use [76]. All these factors affect, directly or indirectly, the vegetation response after fire.

Finally we used pre-fire treatments as the last set of explanatory variables. Within each fire perimeter studied, we considered areas with pre-fire restoration practices on vegetation, and areas that did not receive any pre-fire restoration as two separated treatments. We also included areas near each fire that have not burned and have not received pre-fire vegetation treatments as our third treatment, to represent reference conditions. Due to differences in spatial resolution and projection [37] among the datasets, we conducted a resampling and reprojection of the Landsat TM 5 and the DEM datasets to match the spatial resolution (approximately $250 \mathrm{~m}$ ) and projection (Lambert Azimuthal Equal Area) of the NDVI-MODIS datasets, in order to be able to conduct statistical and spatial analysis of the fires. 
This preprocessing occurred before we derived variables from each dataset. Non-raster datasets were reprojected to match the rest of the datasets.

Figure 5. Explanatory variables used by Multiple Linear Regression (MLR) and Classification and Regression Tree (CART) models. (a) An example of the qualitative variable for pre-fire treatments (only used in CART) (b-d) Variables calculated from the DEM (Slopes, aspect and elevation) (e-g) Estimates for fire severity.
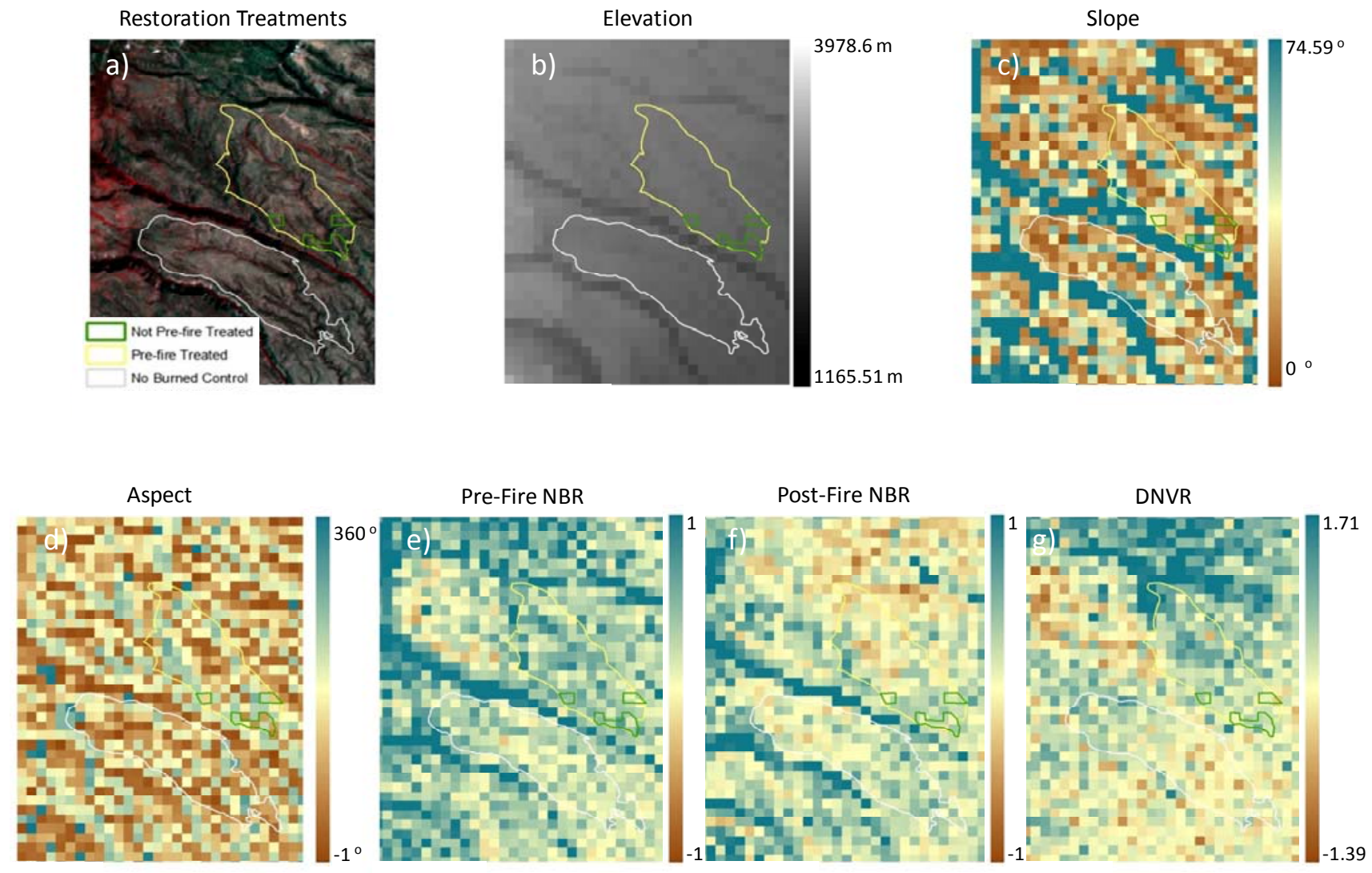

\subsection{Modeling Post-Fire Vegetation Response}

In this section we discuss the statistical model used to assess the environmental factors affecting vegetation response post-fire. Using the environmental proxies previously defined, we: (1) Assess fire factors affecting vegetation response in each treatment; and (2) Analyze the effect of fire treatments along with the rest of the environmental factors in each fire.

\subsubsection{Sampling for Modeling}

For remotely sensed datasets the common output format is a raster with a given spatial resolution, determined by the two dimensional area represented in each one of the image cells, and the magnitude of each of these cells constitutes the average of the reflected energy of the area represented. In this research we use every pixel that is $30 \%$ or more contained within our treatment type as a sample for the specific treatment. Typically if the pixel is divided between two treatment types, the sample was assigned to the treatment that contains more area of the specific cell. 


\subsubsection{Modeling Vegetation Response per Pre-Fire Treatment}

The Stepwise Multiple Linear Regression (MLR) model approach in this study was designed to assess the variation on vegetation response explained by topographic and fire severity effects in each of the treatments per fire. For this analysis, we used vegetation response as our dependent variable, and the same set of independent variables derived for the Classification and Regression Tree (CART) model. However, pre-fire treatments were not included in the analysis since this model analyzes the effects of the rest of the environmental factors on those treatments. For our study we used the iterative process of forward stepwise MLR (with $p<0.1$ ) to assess environmental effects post-fire.

For each of the models generated with the MLR we calculated the adjusted $\mathrm{R}^{2}$ and the standard deviation and the Root Mean Square Error (RMSE). Using the modeled results, we also generated a map of predicted values and a map of residuals for each of the pixels to assess where the model presented more errors.

\subsubsection{Modeling Vegetation Response per Fire}

One of the primary objectives of this work was the assessment of pre-fire treatment effects on postfire vegetation trends. We used a non parametric method to assess the effect of pre-fire vegetation treatments along with the rest of our environmental factors. Our aim was to use the CART modeling approach to evaluate how pre-fire treatments and environmental variables have an effect on post-fire vegetation trends.

An analysis was conducted per-fire as a general model for factors affecting vegetation recovery post-fire. The level of pruning in these models was established by a process of cross-validation, where we developed and fit the entire tree, then evaluated the model using subsets of the entire dataset to produce the tree with the optimal number of nodes. The purpose of this is to improve the prediction of the response variable by the model (vegetation trend post-fire), these methods are extensively explained by Breiman et al. [45,77].

For each of the models generated we created a map with the values estimated for vegetation response after fire. We also plotted the decision tree scheme, showing the decisions taken for each step of the model and the variables contributing to the model development. Finally we generated the chart for the "best pruning level" where we show construction of the smallest tree that is within one standard error of the "minimum-cost" sub-tree. The cost of the tree was calculated as the sum over all terminal nodes of the estimated probability of that node times the node's cost $[45,77]$. Since this is a regression tree, the cost of a node is the average squared error over the observations in that node [45].

We conducted a simple linear regression analysis between the estimated NDVI and the NDVI response per fire to analyze the goodness of fit for the overall model as well as the RMSE.

\section{Results, Analysis and Discussion}

In this section we provide the results and discussion for (1) Post-fire vegetation response as a function of restoration treatments for each fire (2) The MLR approach for the analysis and modeling of the effect and importance of environmental factors in determining post-fire vegetation trends, for each pre-fire treatment per fire, (3) The CART analysis and modeling of the effect and importance of 
environmental variables and restoration treatments per fire. These analyses are used together to explain vegetation trends after disturbance per fire and also per treatment.

\subsection{Post-Fire Vegetation Response}

A series of parameters were estimated from vegetation response after fire (Table 2). All treatments in these fires show that vegetation responses follow a positive trend, increasing their NDVI response in subsequent years after the fire event. Since pre-fire vegetation treatments are not the only vegetation response drivers, we intend to explain the change in NDVI response and variability among treatments in each fire using statistical modeling. However, the fact that our three reference sites show positive trends suggests that vegetation is increasing its photosynthetic activity after years with low production.

In accordance to our assumptions regarding post-fire vegetation response (Figure 1), two fires (Capulin and Frijoles) show slightly lower mean post-fire NDVI values and trajectories compared to their reference areas, during the monsoon season (Table 2). However these differences were minimal for these particular fires. Opposite to this, the La Mesa fire shows slightly higher mean NDVI values for the burned than for the reference areas, suggesting the presence of other processes (possibly drought conditions during 2000 and different vegetation communities, e.g., grass $v s$. forest) controlling photosynthetic activity in this particular area (Table 2). We also observed that initial NDVI (monsoon) responses after each fire did not differ between treated and untreated burned areas. Evaluating fire effects on vegetation composition could provide further insights into changes in vegetation community assemblage and ecosystem function after disturbance.

Table 2. Statistics for the mean monsoon NDVI trend estimated from the MODIS NDVI time series data. Where AF is the mean NDVI monsoon reading the first year after fire, IPY is the increment per year in NDVI units after the first year reading, percent is related to the increment based on the AF and Ratio results from the division between the treatment and the reference areas AF per fire.

\begin{tabular}{|c|c|c|c|c|c|c|}
\hline \multirow{2}{*}{ Fire } & \multirow{2}{*}{ Treatment } & \multicolumn{5}{|c|}{ Mean NDVI } \\
\hline & & $\mathbf{A F}$ & IPY & SD (IPY) & $\%$ (IPY) & Ratio \\
\hline \multirow{2}{*}{ Capulin } & Burned Untreated & 0.3983 & 0.0008 & 0.0008 & 0.2101 & 0.1723 \\
\hline & Reference & 0.4008 & 0.0049 & 0.0022 & 1.2119 & 1.0000 \\
\hline \multirow{3}{*}{$\begin{array}{l}\text { Frijoles } \\
\text { Canyon }\end{array}$} & Burned Treated & 0.6891 & 0.0122 & 0.0103 & 1.7707 & 1.8268 \\
\hline & Burned Untreated & 0.6813 & 0.0192 & 0.0140 & 2.8131 & 2.8692 \\
\hline & Reference & 0.7160 & 0.0067 & 0.0109 & 0.9329 & 1.0000 \\
\hline Mid & Burned Treated & 0.3851 & 0.0054 & 0.0032 & 1.4071 & 0.8949 \\
\hline Elevation & Burned Untreated & 0.3873 & 0.0021 & 0.0015 & 0.5324 & 0.3406 \\
\hline Mesas & Reference & 0.3776 & 0.0061 & 0.0039 & 1.6033 & 1.0000 \\
\hline
\end{tabular}

We calculated the ratio in each fire by dividing the mean NDVI change through the year in each treatment (IPY) by the same change in the reference area (therefore the reference area ratio was always equal to one), to compare the recovery among treatments after adverse environmental conditions and disturbance events. From our results (Table 2) we can perceive that in the Capulin and La Mesa fires, the ratio between our reference areas and the rest of the treatments was always lower than one. This 
suggests that the reference areas increase their monsoon NDVI signal faster than the burned areas, and therefore have a faster response to unfavorable conditions (in the first years).

For the Frijoles Canyon fire, we obtained the opposite results: the reference area had the slowest positive response. However, the reference area in this particular fire had a high NDVI right after fire (higher than the burned areas). This suggests that climatic conditions in this particular fire were more favorable than in the other fires in the first year after disturbance, therefore the response trend could not be expected to increase rapidly for non-disturbed areas if the conditions were almost similar through the years analyzed. Further analysis will require vegetation structure surveys for each fire.

For every fire and reference area (Figure 3) we provide the spatial representation of the vegetation trends (Figure 6). Since one goal for this project was to model the trend of vegetation after each fire, all the observations in each fire were included in the analysis. The trend maps where later used to derive the residuals of the CART and MLR models.

Figure 6. Monsoon trend for each pixel within the fire and the reference areas were computed. For Frijoles Canyon (A) the trend is calculated from 2008 to 2010, for Mid Elevation Mesas (B) from 2000 to 2010, and for Capulin (C) from 2006 to 2010.
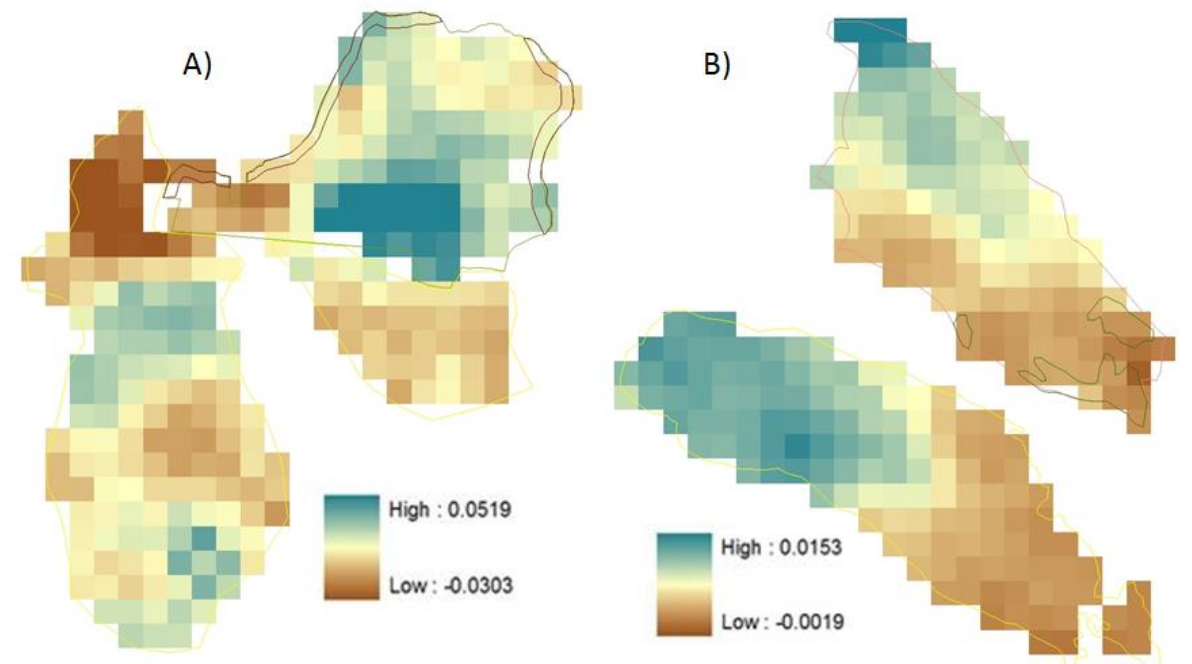

C)

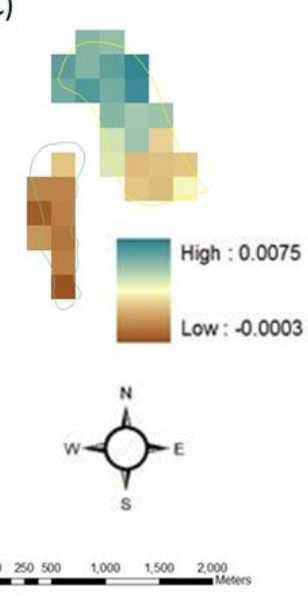

\subsection{Environmental Influence on Vegetation Trends per Pre-Fire Treatment}

\subsubsection{Factors Influencing Post-Fire Vegetation Response}

The Capulin fire (Figure 6(C)) analysis showed that there is strong evidence suggesting the pre- and post-fire NBR, as well as aspect have a strong effect on post-fire vegetation response for the burned and untreated portion (Multiple regression test, ANOVA, $\mathrm{F}_{3,5}=16.5849, p$-value $=0.005$ ). This model explains $90.86 \%$ of the vegetation response variation as a function of post- and pre-fire NBR and aspect. We also found that the post-fire NBR, aspect and elevation have a strong effect on vegetation response in the reference area portion of this particular study site (Multiple regression test, ANOVA, $\mathrm{F}_{3,19}=11.4678, p$-value $=0.0002$ ). This model explained $64.42 \%$ of the variation in vegetation trend as a function of these particular variables. 
Analyses of the Frijoles (Figure 6(A)) fire suggested that aspect and elevation have a strong effect on post-fire vegetation response for the burned and untreated portion (Multiple regression test, ANOVA, $F_{2,83}=23.5481, p$-value $<0.0001$ ). The model explains $36.2 \%$ of the variation in vegetation response, as a function of elevation and aspect. Also, we found that pre- and post-fire NBR, as well as aspect have an effect on post-fire vegetation response in the reference portion of this fire (Multiple regression test, ANOVA, $\mathrm{F}_{3,175}=19.7326, p$-value $\left.<0.0001\right)$. The model explains $25.28 \%$ of the variation in vegetation response as a function of these variables. Finally, we found that pre-fire NBR was the only variable with a significant effect on post-fire vegetation response in the pre-burn treated portion of this fire (Simple Linear regression test, ANOVA, $\mathrm{F}_{1,16}=7.0968$, $p$-value $=0.017$ ), where our model explained $30.73 \%$ of the variation in vegetation response as a function of this variable.

For la Mesa fire (Figure 6(B)), there is evidence suggesting that DNBR and elevation have a moderate effect on post-fire vegetation response for the burned and untreated area (Multiple regression test, ANOVA, $\mathrm{F}_{2,7}=4.0994, p$-value $=0.0663$ ). The model explains $53.94 \%$ of the variation in vegetation response as a function of these two variables. For the reference area, we found strong evidence suggesting that pre- and post-fire NBR, DNBR and elevation have a strong effect on post-fire vegetation response (Multiple regression test, ANOVA, $\mathrm{F}_{4,124}=253.7328, p$-value $<0.0001$ ). This model explained $89.11 \%$ of the vegetation response variation as a function of these variables. And finally in the area that received pre-fire treatment, we found strong evidence that aspect, elevation, slope and DNBR have an strong effect on post-fire vegetation response (Multiple regression test, ANOVA, $\mathrm{F}_{4,99}=69.238, p$-value $<0.0001$ ), here our model explained $73.67 \%$ of the vegetation response variation as a function of this variables.

The variable usage and the fitness for each of the models previously described are illustrated in Table 3. The spatial representation for the estimated NDVI trend after fire and the residuals maps, which denotes how accurate the model was in each location, are provided in Figure 7 . The previous percentages of model explanation where a reference to the adjusted $\mathrm{R}^{2}$ (multiplied by 100), which is a version of the $\mathrm{R}^{2}$ that includes a penalization for the use of non necessary explanatory variables [43].

\subsubsection{Environmental Influences on Post-Fire Vegetation Response}

Topography constituted a key component of our models due to its effect on the local factors; however, our main purpose for the inclusion of these variables is to capture the effects they have in local climatic variability [67]. Due to the number of times that elevation and aspect were used in the models (Table 3), we pose that the topographic arrangement of the terrain has a very significant impact on the overall post-fire vegetation response. This also suggests that variability in local climate and terrain exposure have a strong effect on post-fire vegetation trends. This was expected since these specific areas are dominated by prominent and abrupt changes in terrain structure that create potentially different conditions in short vertical or horizontal distances.

Our analysis also suggests that much of the variability of post-fire vegetation trend can be explained by the variability in fire severity and the vegetation condition pre- and post- fire. The DNBR, and pre- and post- fire NBR where frequently used in our models (Table 3). Pre- and post- fire NBR where more used than the DNBR (Table 3), however they were frequently used together suggesting that vegetation conditions pre- and post- fire affect vegetation trend post-fire. It is expected that vegetation 
condition and magnitude of change due to wildfire events will affect vegetation recovery, since fire effects on biological processes above and below ground [13] are dependent on the severity of the event, and how this severity is distributed spatially.

Each of our models explains a substantial portion of the variation in each pre-fire treatment, suggesting that the selected set of remotely sensed and ancillary datasets used as independent variables captures part of the underlying ecological processes directly and indirectly affecting post-fire vegetation trends. All the models developed here significantly explain variation in vegetation trend (ranging from 0.2528 to .9086 in adjusted $\mathrm{R}^{2}$ values multiplied by 100) as a function of the combination of topographic relief and its properties, and also as a function of vegetation condition and fire severity.

Figure 7. The MLR spatial interpretation for the model results for trends in monsoon NDVI are shown in Frijoles Canyon (A), Mid Elevation Mesas (B) and Capulin (C) fires. The figures A-2, B-2 and C-2 show the difference of the values estimated for monsoon trend (Figure 6); minus the values estimated by the MLR model.
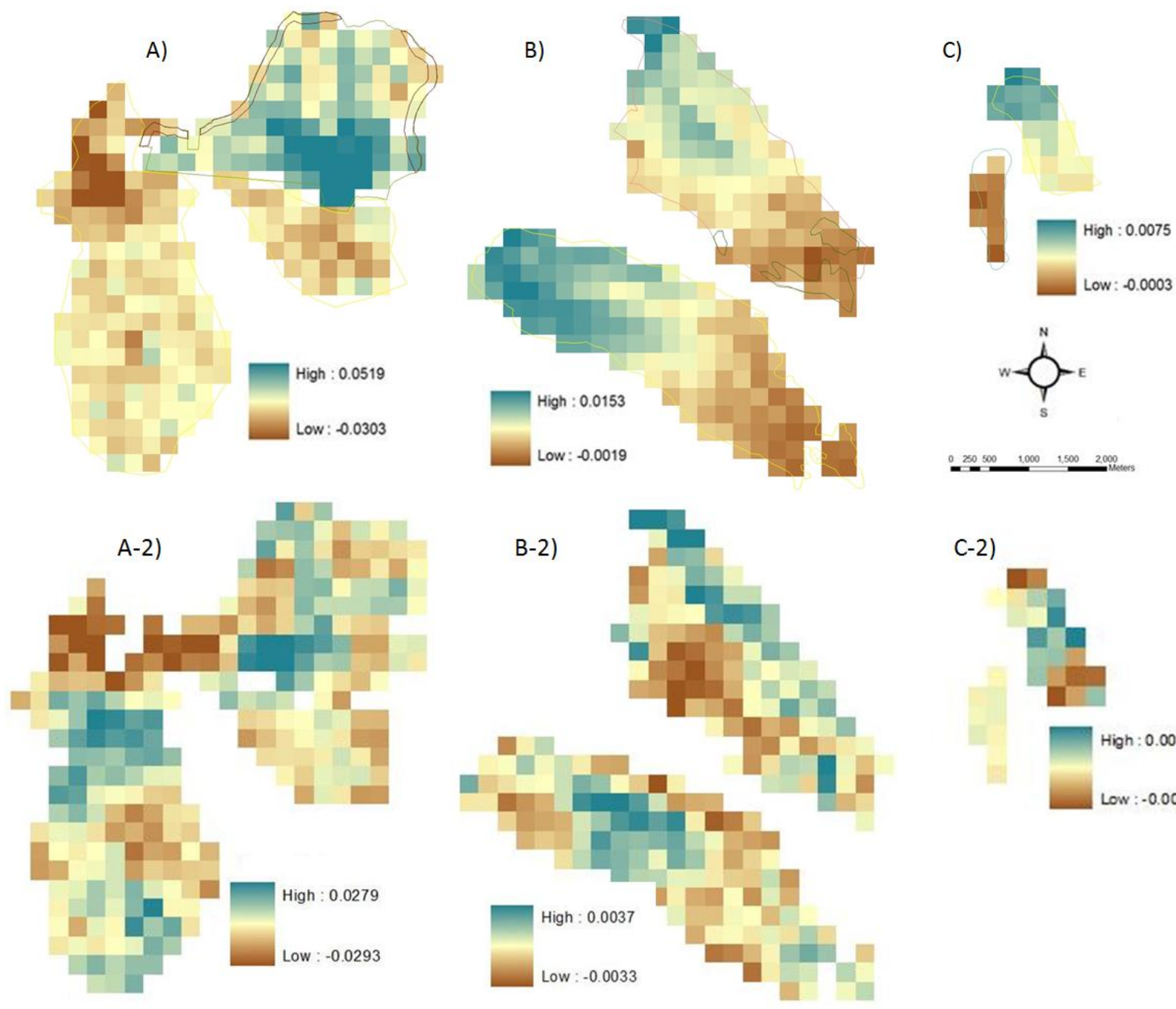

C-2)

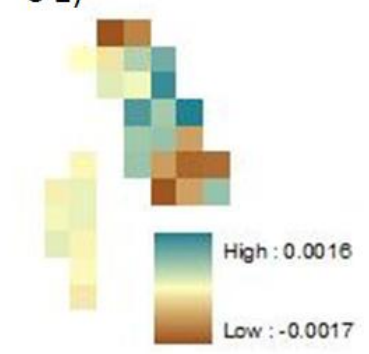


Table 3. Variables that were present in each of the models (per treatment), and the effect each factor has on vegetation response. Here we also show how much each model explains the variation in response, percent of the time each variable was used.

\begin{tabular}{|c|c|c|c|c|c|c|c|c|c|}
\hline Fire Name & $\begin{array}{c}\text { Treatment } \\
\text { Type }\end{array}$ & Pre Fire NBR & Post Fire NBR & DNBR & Elevation & Aspect & Slope & Adj. $R^{2}$ & RMSE \\
\hline \multirow[t]{2}{*}{ Capulin } & $\begin{array}{c}\text { Burned } \\
\text { Untreated }\end{array}$ & - & + & & & + & & 0.854 & 0.0003 \\
\hline & Reference & & + & & + & - & & 0.588 & 0.0011 \\
\hline \multirow{3}{*}{$\begin{array}{l}\text { Frijoles } \\
\text { Canyon }\end{array}$} & $\begin{array}{l}\text { Burned } \\
\text { Treated }\end{array}$ & - & & & & & & 0.264 & 0.0088 \\
\hline & $\begin{array}{l}\text { Burned } \\
\text { Untreated }\end{array}$ & & & & - & - & & 0.347 & 0.0113 \\
\hline & Reference & - & - & & & + & & 0.24 & 0.0095 \\
\hline \multirow{4}{*}{ Mesa Fire } & $\begin{array}{l}\text { Burned } \\
\text { Treated }\end{array}$ & & & + & + & - & + & 0.726 & 0.0017 \\
\hline & $\begin{array}{l}\text { Burned } \\
\text { Untreated }\end{array}$ & & & + & + & & & 0.408 & 0.0011 \\
\hline & Reference & - & - & + & + & & & 0.888 & 0.0013 \\
\hline & Usage (\%) & 50 & 50 & 37.5 & 62.5 & 62.5 & 12.5 & & \\
\hline
\end{tabular}

\subsection{Environmental and Pre-Fire Treatment Influences on Vegetation Trends per Fire}

\subsubsection{Natural and Human Factors Affecting Post-Fire Vegetation Response}

The CART model steps and the rules used in each of the fires to model vegetation response are given in Figure 8. Also, the spatial representation of those results and the residuals map, denoting how accurate the model was in each location, are shown in Figure 9, to illustrate where our models had more or less accuracy compared to the recorded vegetation trends post-fire.

We tested the goodness of fit for the CART results by comparing them to NDVI response in each fire, and also provided the root mean square error (RMSE) in the same NDVI units to show the average distance of the residuals. We found that in the case of Capulin fire the $\mathrm{R}^{2}$ was 0.87 with a RMSE of 0.0009 of NDVI units, for Frijoles fire $\mathrm{R}^{2}$ was 0.47 with a RMSE of 0.0096 of NDVI units, and for La Mesa fire $\mathrm{R}^{2}$ was 0.82 with a RMSE of 0.0016 of NDVI units. These results suggest that the variables included in our models substantially explain vegetation response after fire, and that the pruning level of the CART procedure allows the construction of these models by including the optimal number of factors in them.

The first split of the tree for the Capulin fire indicates that pre-fire treatment is the characteristic separating the burned with no pre-fire treatment, and the reference area. The second split occurs in the reference area, and it suggests that at higher altitudes the vegetation trend has a "steeper slope" (or faster recovery) than at lower elevations.

In the Frijoles fire model (Figure 8) we also have treatment type as the first split, the model suggests that the reference area has to be separated from the burned areas, either treated or untreated, in order to improve the model. The subsequent split shows elevation as the next most important driving factor, suggesting that for the burned areas recovery is faster at lower elevations. Similar results were 
obtained for the reference area, with the difference that at higher elevations the vegetation trend was negative.

For the La Mesa fire model (Figure 8) the first divisor was elevation. The subsequent split at higher elevations is again driven by pre-fire treatment types and at lower elevations a further split in the DEM contributes to shape the response suggesting faster vegetation response at higher elevations.

Figure 8. The regression tree models for post-fire NDVI with the optimal pruning level [45] are shown for the three fires that were evaluated. The rectangles represent the nodes with the variable responsible for the split. In the case of treatments the reference areas (REF), the pre-fire treated burned areas (BT), and the untreated burned areas (BNT) were represented as qualitative values.

Frijoles Fire Model

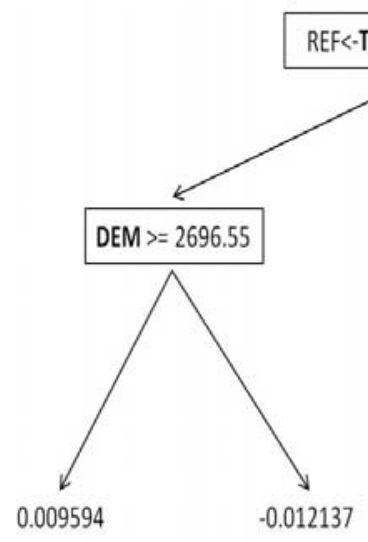

\section{Capulin Fire Model}

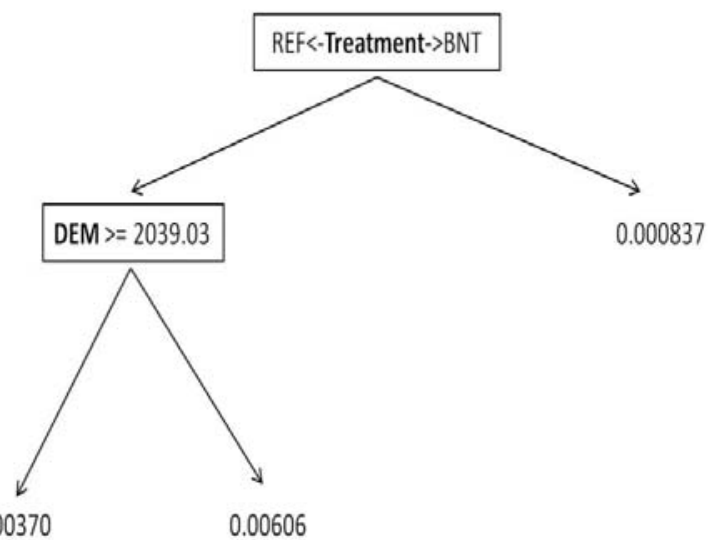

La Mesa Fire Model

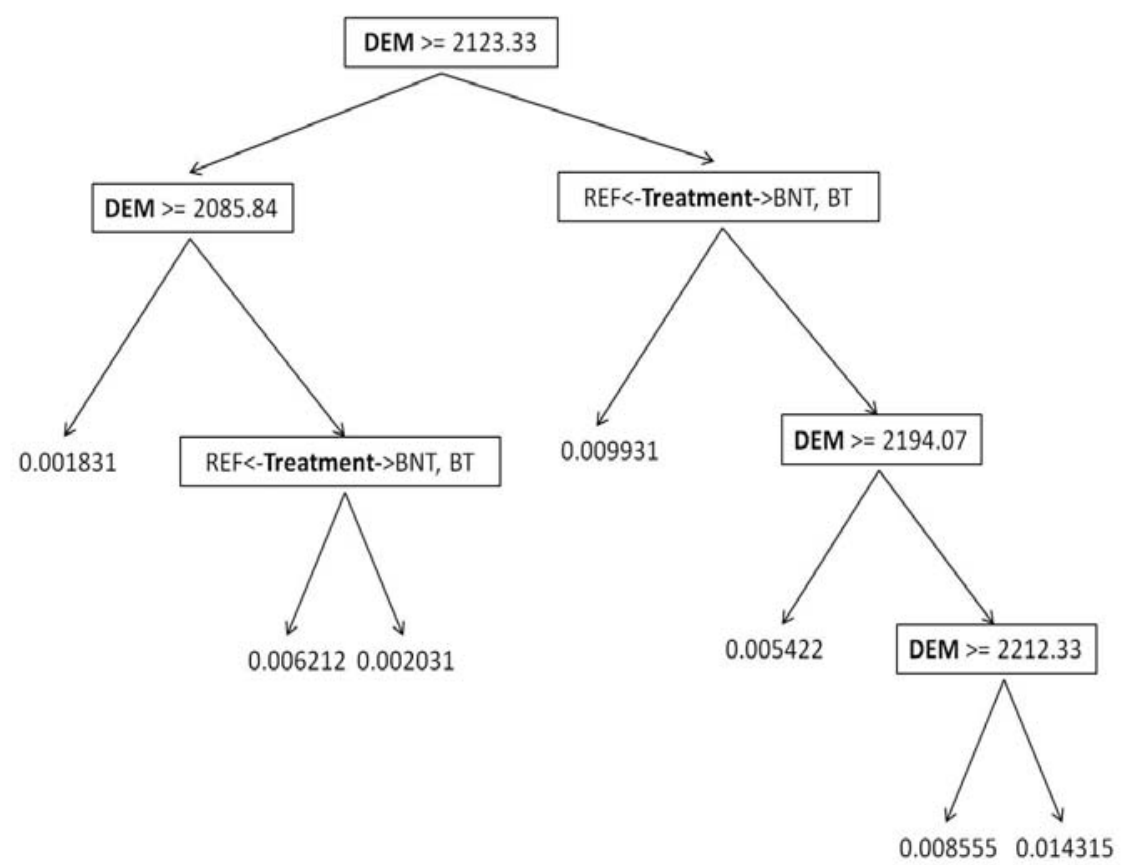

\subsubsection{Pre-Fire Treatment Effects}

According to our models, elevation and pre-fire treatments were the primary response variables that explained post-fire vegetation response variation in the three fires we analyzed. The models show that 
elevation changes have a strong effect of vegetation response after fire, very likely due to its relationship to moisture and climatic conditions. These results along with previous research, discussed in this paper, suggest that climate and terrain condition are some of the important drivers for vegetation response after disturbance.

The objective of pre-fire restoration treatments is to mitigate fire severity and control fire spreading, by modifying vegetation conditions like density and fuel availability. Therefore, it is expected that prefire treated areas will suffer less severe damage due to fire disturbances than untreated areas that burn. In the models generated, the pre-fire treatments were always present as one of the factors affecting vegetation response. However, the models suggest that there was not enough variability between treatment types used in this study to separate the burned treatment types (pre- or post-fire treated), and the model separated only burned from non burned areas.

Figure 9. The CART spatial interpretation for the model results for trends in monsoon NDVI are shown in Frijoles Canyon (A), Mid Elevation Mesas (B) and Capulin (C). The figures A-2, B-2 and C-2 show the difference of the values estimated for monsoon trend (Figure 6), minus the values estimated by the MLR model.
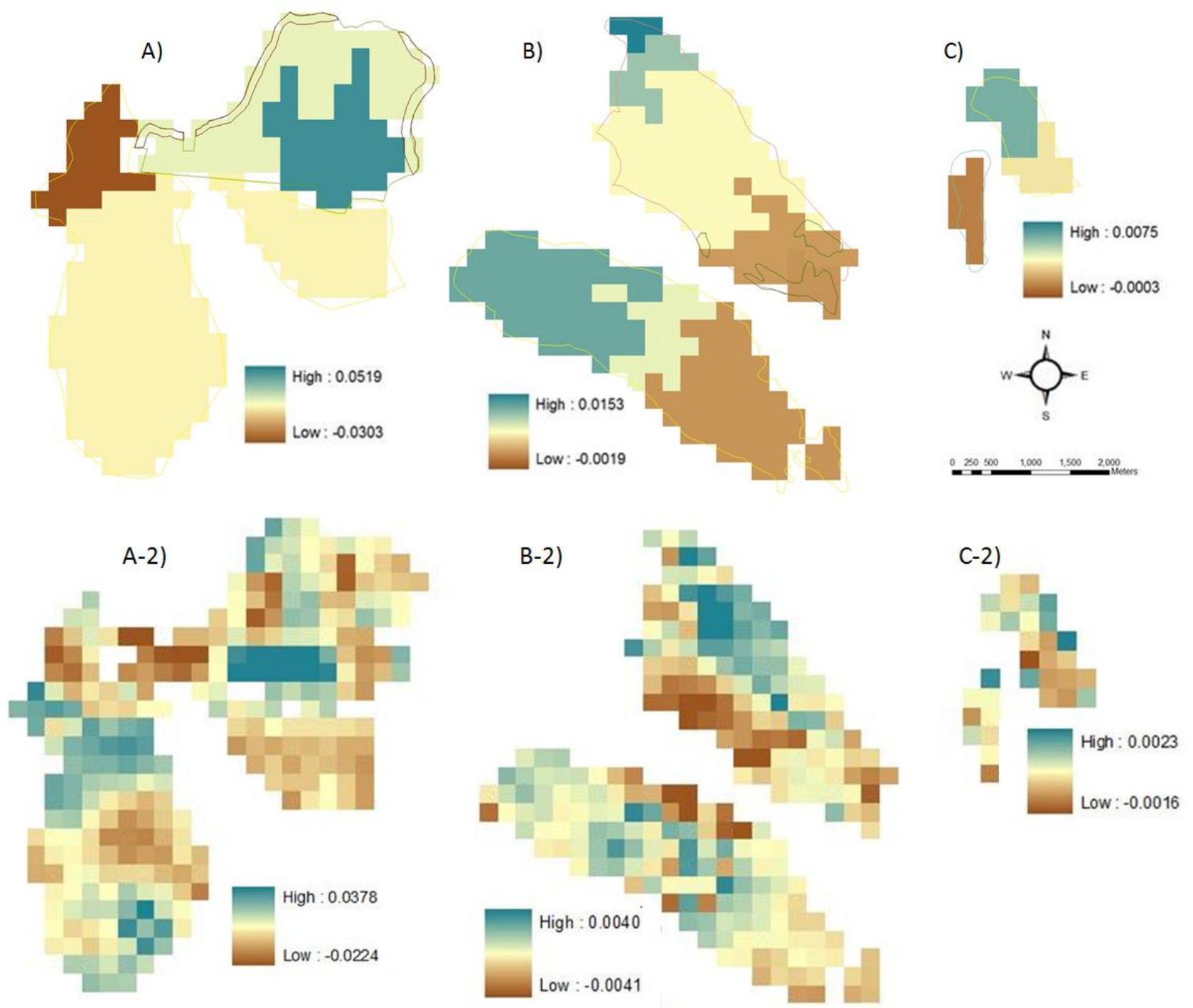


\section{Conclusions and Future Work}

By analyzing post-fire vegetation response for this region, we observed that pre-fire vegetation management practices, topography, and fire severity control a significant portion of post-fire vegetation responses. From the Multiple Linear Regression analysis, our results corroborate that elevation, burn severity and pre- and post-fire vegetation condition strongly influence post-fire vegetation trend. These results agree with previous findings that suggest that these local environmental factors are key for vegetation development and activity $[13,66,68,78]$. The role of these variables changes from place to place according to the characteristics of the terrain and the severity of the fire event.

In this work we used a Classification and Regression Tree model as part of our analysis to assess the effect of pre-fire vegetation treatments on post-fire vegetation response. Our results suggest that pre-fire treatment and pre-fire condition (fuel reduction practices impact on vegetation structure and biomass quantity) have a significant effect on post-fire vegetation trend, when analyzing effects of treatments in combination with the rest of the explanatory variables utilized in this study. However with the level of pruning used, these models do not clearly discriminate between treated and untreated burned areas, only between burned and non-burned areas. This model also suggests elevation as a significant influence for post-fire vegetation trend.

The two modeling approaches used here have advantages. We decided to use the MLR for each of the treatments essentially because all the datasets used for the model were normally distributed, and it was easy to explain their effects on vegetation trend post-fire using the conventional tests. This technique was only used to compare effects of environmental variables in different pre-fire treatment types. The second approach used was the CART model, which presented us with a powerful tool to analyze the effect of pre-fire treatment types and environmental variables on post-fire vegetation response. In this approach the response is modeled through a series of binary splits of the explanatory variables, making it relatively easy to explain (and understand) the effect of each variable in the model. The approaches and methods used in this project constitute a potential tool to help in the development of better strategies to reduce wildfire effects over the landscape. We use a wide array of environmental variables to analyze the response of vegetation after disturbance, and the techniques used give us the opportunity to assess their influence on vegetation response. Further explanation of fire effect on vegetation, will require the inclusion of vegetation structure post fire. Because of the remote sensing tool capabilities, these types of analyses can be conducted spatially and at different scales, providing the opportunity to analyze vegetation response after fire and other disturbance types. This approach could be refined through the use of this methodology to assess other fires and disturbances in the arid southwest portion of the US.

\section{Acknowledgements}

We would like to thank Craig Allen, researcher the USGS Fort Collins Science Center (Jemez Mountain Field Station), Susana Bautista, professor at the Universidad de Alicante, Barron Orr, professor at the University of Arizona, and Dan Malkinson, professor at the University of Haifa, for their help in the development of our analysis. We also thank Kay Beeley (National Park Service) and 
Rebecca Oertel (US Geological Survey) at Bandelier National Monument for their help providing information for this project. We would also like to thank NASA Land Processes Distributed Active Archive Center (LP DAAC), the USGS Earth Resources Observation and Science (EROS) Center and The U.S. Forest Service (USFS), for the information provided. This research was funded by the International Arid Land Consortium (IALC) Grant 08R-01. Any use of trade, product, or firm names is for descriptive purpose only and does not imply endorsement by the US Government.

\section{References}

1. Westerling, A.L.; Hidalgo, H.G.; Cayan, D.R.; Swetnam, T.W. Warming and earlier spring increase western US forest wildfire activity. Science 2006, 313, 940-943.

2. Stephens, S.L.; Moghaddas, J.J.; Edminster, C.; Fiedler, C.E.; Haase, S.; Harrington, M.; Keeley, J.E.; Knapp, E.E.; McIver, J.D.; Metlen, K.; Skinner, C.N.; Youngblood, A. Fire treatment effects on vegetation structure, fuels, and potential fire severity in western US forests. Ecol. Appl. 2009, 19, 305-320.

3. Fulé, P.Z.; Covington, W.W.; Smith, H.B.; Springer, J.D.; Heinlein, T.A.; Huisinga, K.D.; Moore, M.M. Comparing ecological restoration alternatives: Grand Canyon, Arizona. For. Ecol. Manage. 2002, 170, 19-41.

4. Pollet, J.; Omi, P.N. Effect of thinning and prescribed burning on crown fire severity in ponderosa pine forests. Int. J. Wildland Fire 2002, 9, 1-10.

5. Baker, W.L. The landscape ecology of large disturbances in the design and management of nature reserves. Landscape Ecol. 1992. 7, 181-194.

6. White, P.S.; Jentsch, A. The search for generality in studies of disturbance and ecosystem dynamics. Prog. Bot. 2001, 62, 399-450.

7. White, P.S.; Pickett, S.T.A. Natural disturbance and patch dynamics: An introduction. In The Ecology of Natural Disturbance and Patch Dynamics; Academic Press: Orlando, FL, USA, 1985; pp. 3-13.

8. Turner, M.G.; Gardner, R.H.; O’Neill, R.V. Landscape Ecology in Theory and Practice: Pattern and Process; Springer: New York, NY, USA, 2001.

9. McKenzie, D.; Gedalof, Z.; Peterson, D.L.; Mote, P. Climatic change, wildfire, and conservation. Conserv. Biol. 2004, 18, 890-902.

10. Hall, D.K.; Ormsby, J.P.; Johnson, L.; Brown, J. Landsat digital analysis of the initial recovery of burned tundra at Kokolik River, Alaska. Remote Sens. Environ. 1980, 10, 263-272.

11. Turner, M.G.; Romme, W.H. Landscape dynamics in crown fire ecosystems. Landscape Ecol. 1994, 9, 59-77.

12. Turner, M.G.; Romme, W.H.; Gardner, R.H. Pre-fire heterogeneity, fire severity, and early post-fire plant reestablishment in subalpine forests of Yellowstone National Park, Wyoming. Intl J. Wildland Fire 1999, 9, 21-36.

13. Neary, D.G.; Klopatek, C.C.; DeBano, L.F.; Ffolliott, P.F. Fire effects on belowground sustainability: a review and synthesis. For. Ecol. Manage. 1999, 122, 51-71. 
14. Lentile, L.B.; Holden, Z.A.; Smith, A.M.S.; Falkowski, M.J.; Hudak, A.T.; Morgan, P.; Lewis, S.A.; Gessler, P.E.; Benson, N.C. Remote sensing techniques to assess active fire characteristics and post-fire effects. Int. J. Wildland Fire 2006, 15, 319-345.

15. Epting, J.; Verbyla, D.; Sorbel, B. Evaluation of remotely sensed indices for assessing burn severity in interior Alaska using Landsat TM and ETM+. Remote Sens. Environ. 2005, 96, 328-339.

16. Key, C.H.; Benson, N.C. Landscape assessment: Ground measure of severity, the Composite Burn Index, and remote sensing of severity, the Normalized Burn Ratio. In FIREMON: Fire Effects Monitoring and Inventory System; Lutes, D.C., Keane, R.E., Caratti, J.F., Key, C.H., Benson, N.C., Sutherland, S., Gangi, L.J., Eds.; USDA Forest Service, Rocky Mountain Research Station: Fort Collins, CO, USA, 2006.

17. Casady, G.; Leeuwen, W.; Marsh, S. Evaluating post-wildfire vegetation regeneration as a response to multiple environmental determinants. Environ. Model. Assess. 2010, 15, 295-307.

18. Swetnam, T.W.; Baisan, C.H. Historical fire regime patterns in the Southwestern United States since AD 1700. In Fire Effects in Southwestern Fortest: Proceedings of the 2nd La Mesa Fire Symposium; Allen, C.D., Ed.; General Technical Report RM-GTR-286; USDA Forest Service: Fort Collins, CO, USA, 1996.

19. IPCC. Climate Change 2007: Synthesis Report. Contribution of Working Groups I, II and III to the Fourth Assessment; Report of the Intergovernmental Panel on Climate Change; R.K. Pachauri, Reisinger, A., Ed.; Intergovernmental Panel on Climate Change: Geneva, Switzerland, 2007; p. 104.

20. Flannigan, M.D.; Stocks, B.J.; Wotton, B.M. Climate change and forest fires. Sci. Total Environ. 2000, 262, 221-229.

21. Schoennagel, T.; Veblen, T.T.; Romme, W.H. The interaction of fire, fuels, and climate across Rocky Mountain forests. BioScience 2004, 54, 661-676.

22. Touchan, R.; Allen, C.D.; Swetnam, T.W. Fire history and climatic patterns in ponderosa pine and mixed-conifer forests of the Jemez Mountains, Northern New Mexico. In Fire Effects in Southwestern Fortest: Proceedings of the 2nd La Mesa Fire Symposium; Allen, C.D., Ed.; USDA Forest Service: Fort Collins, CO, USA, 1996; p. 33-46.

23. Allen, C.D.; Savage, M.; Falk, D.A.; Suckling, K.F.; Swetnam, T.W.; Schulke, T.; Stacey, P.B.; Morgan, P.; Hoffman, M.; Jon, T.K. Ecological restoration of Southwestern Ponderosa Pine ecosystems: A broad perspective. Ecol. Appl. 2002, 12, 1418-1433.

24. North, M.; Innes, J.; Zald, H. Comparison of thinning and prescribed fire restoration treatments to Sierran mixed-conifer historic conditions. Can. J. For. Res. 2007, 37, 331-342.

25. Agee, J.K.; Skinner, C.N. Basic principles of forest fuel reduction treatments. For. Ecol. Manage. 2005, 211, 83-96.

26. Weatherspoon, P.C.; Skinner, C.N. Effect of thinning and prescribed burning on crown fire severity in ponderosa pine forest. Forest Sci. 1995, 41, 430-451.

27. Stephens, S.L. Evaluation of the effects of silvicultural and fuels treatments on potential fire behaviour in Sierra Nevada mixed-conifer forests. For. Ecol. Manage. 1998, 105, 21-35.

28. Casady, G.M.; van Leeuwen, W.J.D.; Marsh, S.E. Evaluating post-wildfire vegetation regeneration as a response to multiple environmental determinants. Environ. Model. Assess. 2010, 15, 295-307. 
29. Reed, B.C.; Brown, J.F.; Vanderzee, D.; Loveland, T.R.; Merchant, J.W.; Ohlen, D.O. Measuring Phenological Variability from Satellite Imagery. J. Veg. Sci. 1994, 5, 703-714.

30. van Leeuwen, W.J.D.; Casady, G.M.; Neary, D.G.; Bautista, S.; Alloza, J.A.; Carmel, Y.; Wittenberg, L.; Malkinson, D.; Orr, B.J. Monitoring post-wildfire vegetation response with remotely sensed time-series data in Spain, USA and Israel. Int. J. Wildland Fire 2010, 19, 75-93.

31. Zhou, L.M.; Tucker, C.J.; Kaufmann, R.K.; Slayback, D.; Shabanov, N.V.; Myneni, R.B. Variations in northern vegetation activity inferred from satellite data of vegetation index during 1981 to 1999. J. Geophys. Res.-Atmos. 2001, 106, 20069-20083.

32. Casady, G.M.; Marsh, S.E. Broad-scale environmental conditions responsible for post-fire vegetation dynamics. Remote Sens. 2010, 2, 2643-2664.

33. Maselli, F.; Moriondo, M.; Chiesi, M.; Chirici, G.; Puletti, N.; Barbati, A.; Corona, P. Evaluating the effects of environmental changes on the Gross Primary Production of Italian forests. Remote Sens. 2009, 1, 1108-1124.

34. Jensen, J.R. Biophysical remote sensing. Ann. Assoc. Am. Geogr. 1983, 73, 111-132.

35. Tucker, C.J.; Sellers, P.J. Satellite remote sensing of primary production. Int. J. Remote Sens. 1986, 7, 1395-1416.

36. Huete, A.; Didan, K.; Miura, T.; Rodriguez, E.P.; Gao, X.; Ferreira, L.G. Overview of the radiometric and biophysical performance of the MODIS vegetation indices. Remote Sens. Environ. 2002, 83, 195-213.

37. Avery, T.E.; Berlin, G.L. Fundamentals of Remote Sensing and Airphoto Interpretation, 5th ed.; Prentice Hall: Upper Saddle River, NJ, USA, 1992.

38. Jensen, J.R. Introductory Digital Image Processing: A Remote Sensing Perspective, 3rd ed.; Pearson Prentice Hall: Upper Saddle River, NJ, USA, 2005.

39. White, J.D.; Ryan, K.C.; Key, C.C.; Running, S.W. Remote sensing of forest fire severity and vegetation recovery. Int. J. Wildland Fire 1996, 6, 125-136.

40. van Leeuwen, W.J.D. Monitoring the effects of forest restoration treatments on post-fire vegetation recovery with MODIS multitemporal data. Sensors 2008, 8, 2017-2042

41. Wimberly, M.C.; Cochrane, M.A.; Baer, A.D.; Pabst, K. Assessing fuel treatment effectiveness using satellite imagery and spatial statistics. Ecol. Appl. 2009, 19, 1377-1384.

42. Roy, D.P.; Boschetti, L.; Trigg, S.N. Remote sensing of fire severity: Assessing the performance of the normalized burn ratio. IEEE Geosci. Remote Sens. Lett. 2006, 3, 112-116.

43. Ramsey, F.L.; Schafer, D.W. The Statistical Sleuth: A Course in Methods of Data Analysis, 2nd ed.; Pacific Grove: Duxbury, CA, USA, 2002.

44. Murthy, S.K. Automatic construction of decision trees from data: A multi-disciplinary survey. Data Min. Knowl. Disc. 1998, 2, 345-389.

45. Breiman, L.; Friedman, J.H.; Olshen, R.A.; Stone, C.G. Classification and Regression Trees; Wadsworth International Group: Belmont, CA, USA, 1984.

46. De'ath, G.; Fabricius, K.E. Classification and regression trees: A powerful yet simple technique for ecological data analysis. Ecology 2000, 81, 3178-3192.

47. Davenport, D.W.; Wilcox, B.P.; Breshears, D.D. Soil morphology of canopy and intercanopy sites in piilon-juniper woodland. Soil Sci. Soc. Am. J. 1996, 60, 1881-1887. 
48. Wilcox, B.P.; Newman, B.D.; Allen, C.D.; Reid, K.D.; Brandes, D.; Pitlick, J.; Davenport, D.W. Runoff and Erosion on the Pajarito Plateau: Observations from the Field; New Mexico Geological Society: Socorro, NM, USA, 1996.

49. Conley, W.; Sivinski, R.; White, G. Responses of Elk (Cervus elaphus) and Mule Deer (Odocoileus hemionus) to Wildfire: Changes in Utilization and Migration Patterns; Bandelier National Monument: Los Alamos, NM, USA, 1979; p. 88.

50. Rupp, S. Effects of Grazing and Trampling by Rocky Mountain Elk (Cervus elaphus nelsoni) on the Vegetative Community of Bandelier National Monument, New Mexico. M.S. Thesis, Texas Tech University, Lubbock, TX, USA, 2000.

51. Balice, R.G.; Miller, J.D.; Oswald, B.P.; Edminster, C.; Yool, S.R. Forest Surveys and Wildfire Assessment in the Los Alamos Region 1998-1999; Los Alamos National Laboratory: Los Alamos, NM, USA, 2000; p. 86.

52. Gamon, J.A.; Field, C.B.; Goulden, M.L.; Griffin, K.L.; Hartley, A.E.; Joel, G.; Penuelas, J.; Valentini, R. Relationships between NDVI, canopy structure, and photosynthesis in three Californian vegetation types. Ecol. Appl. 1995, 5, 28-41.

53. Epiphanio, J.N.; Huete, A.R. Dependence of NDVI and SAVI on sun/sensor geometry and its effect on fAPAR relationships in Alfalfa. Remote Sens. Environ. 1995, 51, 351-360.

54. Myneni, R.B.; Williams, D.L. On the relationship between FAPAR and NDVI. Remote Sens. Environ. 1994, 49, 200-211.

55. Richard, Y.; Poccard, I. A statistical study of NDVI sensitivity to seasonal and interannual rainfall variations in Southern Africa. Int. J. Remote Sens. 1998, 19, 2907-2920.

56. Schloss, A.L.; Kicklighter, D.W.; Kaduk, J.; Wittenberg, U.; The Participants of the Potsdam NPP Model Intercomparison. Comparing global models of terrestrial net primary productivity (NPP): Comparison of NPP to climate and the Normalized Difference Vegetation Index (NDVI). Global Change Biol. 1999, 5, 25-34.

57. Myneni, R.B.; Ramakrishna, R.; Nemani, R.; Running, S.W. Estimation of global leaf area index and absorbed par using radiative transfer models. IEEE Trans. Geosci. Remote Sens. 1997, 35, 1380-1393.

58. Coops, N.C.; Waring, R.H.; Landsberg, J.J. Assessing forest productivity in Australia and New Zealand using a physiologically-based model driven with averaged monthly weather data and satellite-derived estimates of canopy photosynthetic capacity. For. Ecol. Manage. 1998, 104, 113-127.

59. Chavez, P.S., Jr. Image-based atmospheric corrections-Revisited and improved. Photogramm. Eng. Remote Sens. 1996, 62, 1025-1036.

60. Miller, J.D.; Thode, A.E. Quantifying burn severity in a heterogeneous landscape with a relative version of the delta Normalized Burn Ratio (dNBR). Remote Sens. Environ. 2007, 109, 66-80.

61. Longley, P.A.; Goodchild, M.F.; Maguire, D.J. Geographic Information Systems and Science, 2nd ed.; John Wiley and Sons: Chichester, UK, 2005.

62. Jenson, S.K.; Domingue, J.O. Extracting topographic structure from digital elevation data for geographic information system analysis. Photogramm. Eng. Remote Sensing 1988, 54, 1593-1600.

63. Moore, I.D.; Grayson, R.B.; Ladson, A.R. Digital terrain modeling-A review of hydrological, geomorphological, and biological applications. Hydrol. Processes 1991, 5, 3-30. 
64. Daly, C.; Gibson, W.P.; Taylor, G.H.; Johnson, G.L.; Pasteris, P. A knowledge-based approach to the statistical mapping of climate. Clim. Res. 2002, 22, 99-113.

65. Daly, C.; Neilson, R.P.; Phillips, D.L. A statistical-topographic model for mapping climatological precipitation over mountainous terrain. J. Appl. Meteorol. Clim. 1994, 33, 140-158.

66. Raupach, M.R.; Finnigan, J.J. The influence of topography on meteorological variables and surface-atmosphere interactions. J. Hydrol. 1997, 190, 182-213.

67. Flores, A.N.; Ivanov, V.Y.; Entekhabi, D.; Bras, R.L. Impact of hillslope-scale organization of topography, soil moisture, soil temperature, and vegetation on modeling surface microwave radiation emission. IEEE Trans. Geosci. Remote Sens. 2009, 47, 2557-2571.

68. Swanson, F.J.; Kratz, T.K.; Caine, N.; Woodmansee, R.G. Landform effects on ecosystem patterns and processes. BioScience 1988, 38, 92-98.

69. Ali, G.A.; Roy, A.G.; Legendre, P. Spatial relationships between soil moisture patterns and topographic variables at multiple scales in a humid temperate forested catchment. Water Resour. Res. 2010, 46, 1-17.

70. Allan, J.D.; Erickson, D.L.; Fay, J. The influence of catchment land use on stream integrity across multiple spatial scales. Freshwater Biol. 1997, 37, 149-161.

71. Begum, F.; Bajracharya, R.M.; Sharma, S.; Sitaula, B.K. Influence of slope aspect on soil physico-chemical and biological properties in the mid hills of central Nepal. Int. J. Sustain. Dev. World 2010, 17, 438-443.

72. Pachepsky, Y.A.; Timlin, D.J.; Rawls, W.J. Soil water retention as related to topographic variables. Soil Sci. Soc. Am. J. 2001, 65, 1787-1795.

73. Pan, B.; Geng, H.; Hu, X.; Sun, R.; Wang, C. The topographic controls on the decadal-scale erosion rates in Qilian Shan Mountains, N.W. China. Earth Planet Sc. Lett. 2010, 292, 148-157.

74. Pazzaglia, F.J.; Brandon, M.T. Macrogeomorphic evolution of the post-Triassic Appalachian mountains determined by deconvolution of the offshore basin sedimentary record. Basin Res. 1996, $8,255-278$.

75. Bertoldi, G.; Notarnicola, C.; Leitinger, G.; Endrizzi, S.; Zebisch, M.; Della Chiesa, S.; Tappeiner, U. Topographical and ecohydrological controls on land surface temperature in an Alpine catchment. Ecohydrology 2010, 3, 189-204.

76. Herold, M.; Goldstein, N.C.; Clarke, K.C. The spatiotemporal form of urban growth: Measurement, analysis and modeling. Remote Sens. Environ. 2003, 86, 286-302.

77. Breiman, L.; Friedman, J.H.; Olshen, R.A.; Stone, C.G. Classification and Regression Trees; Chapman \& Hall: New York, NY, USA, 1993.

78. Turner, M.G.; Romme, W.H.; Gardner, R.H.; Hargrove, W.W. Effects of fire size and pattern on early succession in Yellowstone National Park. Ecol. Monogr. 1997, 67, 411-433.

(C) 2012 by the authors; licensee MDPI, Basel, Switzerland. This article is an open access article distributed under the terms and conditions of the Creative Commons Attribution license (http://creativecommons.org/licenses/by/3.0/). 